\title{
THE GROWTH OF COMPETITIVENESS AS A RESULT OF THE CHANGES OF WAGE AND EMPLOYMENT
}

\author{
Irena Danilevičiene $\dot{e}^{1,2}$ \\ ${ }^{1}$ Department of Finance Engineering, Vilnius Gediminas Technical University, \\ Saulètekio al. 11, LT-10223, Vilnius \\ ${ }^{2}$ Labour Market Research Institute, Lithuanian Social Research Centre, \\ A. Goštauto g. 11, LT-01108, Vilnius \\ E-mail: irena.danileviciene@vgtu.lt
}

\begin{abstract}
The concept of competitiveness is a multidimensional and is closely related to the country's ability to adapt to a constantly changing environment. The growth of competitiveness depends on the main aspects of wage and employment, which is influenced by micro and macro factors. The objective of this article is to assess the link between the wage, employment and competitiveness. The following tasks have been implemented: to analyse the scientific literature about competitiveness and its factors; to reveal the changes of wages and employment; to assess the impact of main factors on competitiveness. In the article, the following methods of analysis are used: an analysis and summarize of the scientific literature, analysis of the statistical data, correlation-regression analysis.
\end{abstract}

Keywords: competitiveness, development, economic growth, efficiency, employment, wage.

JEL Classification: E24; J21; J31; Q52.

\section{Introduction}

Nowadays the competitiveness is a conditional and dynamic economic concept, which by different aspects is analysed by many researchers. The term of competitiveness has appeared in the early $20^{\text {th }}$ century in the United States, where comparative economic research was done. Then the competitiveness was defined as the ability to provide services and products for the market at the right time, in the right place and in the appropriate form (Lotfi \& Karim, 2016).

The competitiveness become especially popular in the $7^{\text {th }}$ decade of $20^{\text {th }}$ century. Competitiveness is defined as the ability to reach the international competitiveness and benefit, an appropriate income level and a relatively high level of employment in the various level (Schwab \& Porter, 2007; Borowiecki \& Siuta-Tokarska, 2015; Lotfi \& Karim, 2016). In this case, it is very important to establish an adequate wage and to ensure a stable level of employment.

The objective of this article is to assess the link between the wage, employment and competitiveness. The following tasks have been implemented: to analyse the scientific literature about competitiveness, wage and employment; to reveal the changes of wages and employment; to assess the impact of wages and employment on competitiveness.
In the article, the following methods of analysis are used: an analysis and summarize of the scientific literature, analysis of the statistical data, correlation-regression analysis.

\section{The concept of competitiveness and its factors}

\subsection{Theoretical aspects of competitiveness}

The concept of competitiveness is a multidimensional feature that derives from the characteristic of the internal environment and is related to the country's ability to adapt to the constantly changing socio-economic situation. For the economic development and competitive success due to other regions, it is important to create new conditions for economic development (Walczak, 2010).

In the context of globalization it is necessary to compete with other by capital size, the level of technical knowledge and special skills (Misala, 2011). It follows that the competitive advantage is possible only by acquiring new and having the necessary skills and having the appropriate resources.

The main objective of competitiveness is to create the preconditions for learning and to adapt the modern technologies in activity (Yordan, Nasution, \& Buang, 2017). In this way the productivity is increased, deficits and traditional barriers

(C) 2018 The Authors. Published by VGTU Press. This is an open-access article distributed under the terms of the Creative Commons Attribution License (CC-BY 4.0), which permits unrestricted use, distribution, and reproduction in any medium, provided the original author and source are credited. 
is reduced and the real income of the population is increased and all is reflected in improving of the standards of population living (Dwyer \& Kim, 2003; Lotfi \& Karim, 2016). This multidimensional phenomenon can be analysed at various levels (Borowiecki \& Siuta-Tokarska, 2015; Kleinhanss, 2015; Lotfi \& Karim, 2016): companies, sectoral, regional, country's (national) and international. Further competitiveness is analysed at the country's (macro) level.

M. Porter was widely started to analysed the competitiveness in macro level in $1990 \mathrm{y}$. and then he moved the competitiveness model from micro to country and regional level (Bruneckienè \& Kilijonienè, 2011).

The country's competitiveness is known as a complex category characterized by the participation in market, high growth of real income, the changes of production resources and productivity (the efficient use of resources), high potential, employment level and economic efficiency, strong exchange rate (Latruffe, 2010; Borowiecki \& Siuta-Tokarska, 2015; Kleinhanss, 2015).

Here are several aspects of country's competitiveness assessment (Meilienė \& Snieška, 2010; Bruneckienė \& Kilijonienè, 2011):

- the foreign trade approach (the supporters of foreign trade competitiveness define as a mutual competition for international markets, when competitiveness increases with the increase of export volumes on the world market and depending on the prices and other factors);

- the country's productivity approach (the country's objective is to create high and ever-increasing living standards for the country's citizens depending on the country's companies' ability to achieve high levels of productivity, continuous improvement, sales and adaptation abilities and local attractiveness);

- the approach of the people ability to ensure the prosperity (the competitiveness is understood as the ability to create the conditions of prosperity, provide them a possibility to gain a work (high income) and social guarantees (education, health care, to ensure a democracy and social justice).

The country's competitiveness is related to its level of development and the structure of the economy because it is defined as a set of institutions, policies and factors that determine the level of a country's competitiveness (Schwab \& Porter, 2007). The country's ability is to create such economic, social, infrastructural and institutional conditions that achieve better activity results, while citizens met their needs better than other.

The country's competitiveness is also often defined as a successful foreign trade, the country's productivity, its ability to ensure the wealth of citizens (Rakauskienė \& Tamošiūnienè, 2013). The implementation of this condition is characterized by its ability to be a competitive and to use its knowledge to achieve social and economic cohesion (Bruneckienè \& Kilijonienè, 2011; Yordan et al., 2017).

The main reasons for the growth of the importance of competitiveness are emerging:

- the globalization of the economy which is open to the movement of goods, services, capital, people and knowledge and also is stimulated by the improvement of information technology and transport systems;

- the concentration of population, where is accumulated potential, which creates new requirements, needs and opportunities;

- the growth of economic and social life, when the results of science in practice are used more efficient.

It follows that from the other European Union countries point of view, in order to assess the country's level of competitiveness many factors need to be taken into account and there is the opportunities to evaluate the competitiveness in several aspects.

In this article for the assessment the country's productivity approach is used and it shows that a competitive advantage is achieved when a country is capable to create a high-quality product (or service) and efficiently use its available capabilities. An important aspect in the assessment is the systematization of factors contributing to competitiveness.

\subsection{Influence of the factors to competitiveness}

As already mentioned, the competitiveness is a multidimensional phenomenon and it is influenced by many factors. These factors can be grouped into two larger groups: internal and external factors. The factors that influence the competitiveness are summarized in Figure 1.

Figure 1 shows that all factors that affect the competitiveness of the country are divided into internal and external. Most of the internal and external factors have a strong impact on competitiveness and this is more qualitative than quantitative. 


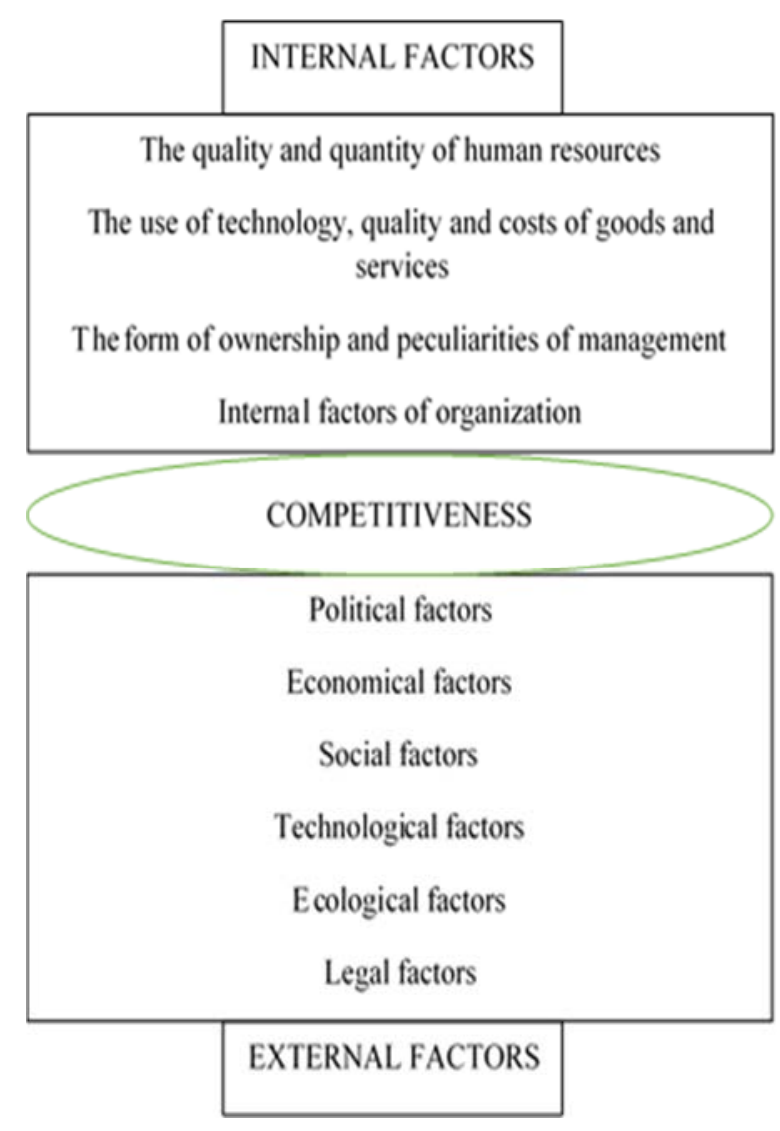

Figure 1. Factors affecting competitiveness (source: compiled by author based on Borowiecki \&

Siuta-Tokarska, 2015; Abreu-Novais, Ruhanen, \& Arcodia, 2016; Lotfi \& Karim, 2016)

Internal factors affect the competitiveness of a country through the competitiveness of individual industries. The internal factors can be divided into larger groups (Borowiecki \& Siuta-Tokarska, 2015; Gołębiewski \& Podlińska, 2015; Wychowanek, 2015): human capital factors (quantity and quality of human resources, qualification of employees), the features of products and services (quality and accessibility of resources, application of technology, volume and costs of production, quality of goods and services), features of organization (industry) (organization ownership form, variety of management methods, features of organization and management, public relations).

External factors are global and are classified into several groups (Borowiecki \& Siuta-Tokarska, 2015; Gołębiewski \& Podlińska, 2015; Wychowanek, 2015; Abreu-Novais et al., 2016; Lotfi \& Karim, 2016): productivity (understood through the improvement of work organization, positive changes of the quality of production factors, improvement of the production process and the efficient distribution of resources) and the fac- tors of efficiency (quality of higher education, efficiency of labour market, market size), political factors (legal norms, custom tariffs), trade liberalization (global demand (compiled the possibility to choose foreign partners appropriately), foreign exchange rate (exchange rate decline affects export and limits external effect, devaluation encourages development and international competitiveness), foreign influence (foreign capital is a source of funds, creating a dynamic comparative advantage while the investments stimulate the development of technological innovation and improve the productivity of factors), economic factors (macroeconomic stability, price level, understanding of the behavior of competitors, satisfaction of customer needs), demographic factors, technological and innovative factors (technological provision, level of the development of business and innovation), natural factors, cultural factors, country's policy in the region, globalization, communication networks, ecological norms, technical norms, financial situation.

Meilienè and Snieška (2010) suggests that factors of country's competitiveness are divided into four groups: totally uncontrolled factors (e.g. geographic conditions), short-term uncontrolled factors that can be controlled only in the long-term (infrastructure, qualification), higher level factors (controlled by the institutions whose level of control depends on a political aspects and lobbying) (government policy) and directly controlled factors (resources).

In this article greater attention is paid to the economic and social factors, especially wage and employment and their impact on productivity. So, the initial theoretical relationship between these three factors is presented.

\subsection{Theoretical relations of wage and employment with competitiveness}

One of the main tasks of the country is the fostering of economic development, which is closely related with the country's ability to stay competitive, to use the available labour and capital appropriate and to ensure the growth of the gross domestic product amount. In the 2.1. section of the article the concept of competitiveness is deeply analysed and concludes that competitiveness is one of the key factor affecting economic development. This effect is possible using the certain transmission channels, which manifest themselves as aspects of competitiveness.

Competitiveness is based on increased economic capacity and innovative attractiveness, 
greater accessibility, adaptability, productivity and knowledge-based economy elements. It follows that growth of competitiveness is driven by lifelong learning, employment, labour force adaptation to market conditions, entrepreneurship (Žitkus \& Mickevičienè, 2013). The abilities of competitiveness creates the preconditions to create modern, knowledge-based society, sustainable economic growth, the growth of country's economic competitiveness and accordingly sustainable (smart) growth (Camagni \& Capello, 2014).

The concept of labour productivity, employment (or unemployment) and wage are an important economic and legal problem and their relationships are closely related to macro and micro level of competitiveness. The relations between wage and productivity are based on the fact that higher capital increases labour demand and wages while wage growth promotes the growth of productivity. From the macroeconomic perspective globalization and the openness of countries to international trade, the growth of productivity and wage becomes the key factors that determine the international competitiveness of countries. In this point of view, the competitiveness is understood as the ability to compete with time, productivity, quality and innovation (Kleinhanss, 2015). The competitiveness perfectly shows the share of exported production, productivity and operating costs while export is an important indicator of international competitiveness (Meilienė \& Snieška, 2010; Borowski, 2015). The growth of competitiveness, and especially productivity, promotes the economic development (Karaalp-Orhan, 2017), therefore the most often object of scientific research is the relationship between productivity, wage and level of employment (or unemployment) (Table 1).

Researches results of scientists (Alexander, 1993; Strauss \& Wohar, 2004; Mora et al., 2005; Yusof, 2008; Narayan \& Smyth, 2009; Trpeski \& Tashevska, 2009; Verbic \& Kuzmin, 2009; Karaalp-Orhan, 2017) shows that there is a link between productivity, real wages and employment. Wage and employment level have a significant positive long-term impact on productivity. The growth of wage and employment leads to the increase in labour costs and to a possible loss of job (Karaalp-Orhan, 2017). The link between wage, productivity an inflation is also analysed (Hondroyiannis \& Papapetrou, 1997; Bildirici \& Alp, 2008; Kumar, Webber, \& Perry, 2009). The growth of inflation and productivity is negatively related as inflation reduced incentives to work, investment has no return and capital price is growing.

Table 1. The scientific researches on the relationship between wages, employment and productivity (source: compiled by author based on the scientific literature)

\begin{tabular}{|c|c|c|c|}
\hline Source & $\begin{array}{l}\text { Analysed } \\
\text { countries }\end{array}$ & $\begin{array}{c}\text { Analysed } \\
\text { period }\end{array}$ & Results \\
\hline $\begin{array}{l}\text { Alexan- } \\
\text { der } \\
(1993)\end{array}$ & $\begin{array}{l}\text { United } \\
\text { Kingdom }\end{array}$ & $\begin{array}{c}1955- \\
1991\end{array}$ & $\begin{array}{l}\text { A positive rela- } \\
\text { tions between } \\
\text { productivity, } \\
\text { wage and unem- } \\
\text { ployment. } \\
\end{array}$ \\
\hline $\begin{array}{l}\text { Strauss } \\
\text { and } \\
\text { Wohar } \\
(2004)\end{array}$ & $\begin{array}{l}\text { United } \\
\text { States of } \\
\text { America }\end{array}$ & $\begin{array}{c}1956- \\
1996\end{array}$ & $\begin{array}{l}\text { The relationship } \\
\text { between price } \\
\text { level, wage and } \\
\text { productivity is } \\
\text { possible only in } \\
\text { a long-term. }\end{array}$ \\
\hline $\begin{array}{l}\text { Mora, } \\
\text { Lopez- } \\
\text { Tamayo, } \\
\text { and Su- } \\
\text { rinach } \\
(2005)\end{array}$ & $\begin{array}{l}\text { European } \\
\text { Union } \\
\text { countries }\end{array}$ & $\begin{array}{c}1981- \\
2001\end{array}$ & $\begin{array}{l}\text { The relations be- } \\
\text { tween wage, } \\
\text { productivity, } \\
\text { wage and labour } \\
\text { costs are existed. }\end{array}$ \\
\hline $\begin{array}{l}\text { Yusof } \\
(2008)\end{array}$ & $\begin{array}{l}\text { Malaysian } \\
\text { industry }\end{array}$ & $\begin{array}{c}1992- \\
2005\end{array}$ & $\begin{array}{l}\text { Wage negatively } \\
\text { affect employ- } \\
\text { ment if system } \\
\text { of remuneration } \\
\text { for work results } \\
\text { is applied. }\end{array}$ \\
\hline $\begin{array}{l}\text { Narayan } \\
\text { and } \\
\text { Smyth } \\
(2009)\end{array}$ & $\begin{array}{l}\text { G7 coun- } \\
\text { tries }\end{array}$ & $\begin{array}{c}1960- \\
2001\end{array}$ & $\begin{array}{l}\text { The positive sta- } \\
\text { tistical relation } \\
\text { between wage } \\
\text { and productivity } \\
\text { is existed. } \\
\end{array}$ \\
\hline $\begin{array}{l}\text { Trpeski } \\
\text { and Ta- } \\
\text { shevska } \\
(2009)\end{array}$ & $\begin{array}{l}\text { Republic } \\
\text { of Mace- } \\
\text { donia }\end{array}$ & $\begin{array}{l}1995- \\
2007\end{array}$ & $\begin{array}{l}\text { There is a rela- } \\
\text { tion between } \\
\text { productivity and } \\
\text { wage, although } \\
\text { productivity by } \\
\text { other factors is } \\
\text { more influenced. }\end{array}$ \\
\hline $\begin{array}{l}\text { Verbic } \\
\text { and } \\
\text { Kuzmin } \\
(2009)\end{array}$ & Slovenia & $\begin{array}{l}1998- \\
2007\end{array}$ & $\begin{array}{l}\text { The relationship } \\
\text { between wage } \\
\text { and productivity } \\
\text { is existed. }\end{array}$ \\
\hline $\begin{array}{l}\text { Karaalp- } \\
\text { Orhan } \\
(2017)\end{array}$ & Turkey & $\begin{array}{c}2007- \\
2016\end{array}$ & $\begin{array}{l}\text { There is a rela- } \\
\text { tion between } \\
\text { productivity, } \\
\text { real wages and } \\
\text { unemployment } \\
\text { level. }\end{array}$ \\
\hline
\end{tabular}


It is necessary to mention that here are two possibilities for increasing productivity: to use the available resources efficiently or to increase the amount of human resources (to increase employment). The modern competitive environment also creates the preconditions for achieving the maximum interest of employees to increase labour productivity, which can be achieved through the application of appropriate material motivation and scientifically based wage level determination. In the case of a more competitive economy it is possible to increase the level of income of the population (Wakeford, 2004; Trpeski \& Tashevska, 2009; Šileika, Tamašauskienè, \& Bartelienè, 2010; Karaalp-Orhan, 2017). In this point of view labour productivity is an expression of the efficient use of labour force. The lower than the average European Union countries productivity level leads to the higher demand for unskilled or less skilled labour force and at the same time greater quantitative dependence on labour force as a key factor of productivity (Šileika et al., 2010).

The growth of productivity increases the amount of production, which is produced over the same period and the public welfare is growing. Respectively business subjects can increase wage and dividends while maintaining the same price level and increasing production volume (Trpeski \& Tashevska, 2009; Šileika et al., 2010). Employee's of the companies gain higher wage, because (Trpeski \& Tashevska, 2009): wages affect efficiency and accordingly human health, improve the quality of labour force, motivate employees to put on more efforts and reduce the rotation of staff, which means that employees will be able to work more productively, faster and longer in one work place. It means that productivity growth has a positive impact on economic growth and wage growth, while shareholders will receive a higher return from the invested capital. If high wages are results from the increased productivity it means that higher wages help to increase the profit of companies. Economic theory argues that the growth of labour demand, which depends on the growth of marginal work product, leads to the growth of wage and adverse - the declining demand leads to the decreasing of wage level. Higher wage also encourage to give more efforts and avoid dismiss (Wakeford, 2004; Kumar et al., 2009). Meanwhile, the average wage rate is growing slowly if job supply is stable.

In summary and based on the results of scientific research it can be argued that theoretically there is a relation between wage, employment and productivity. In the further chapter author's research results and the relationship between mentioned factors in practice are shown.

\section{Analysis of factors influencing competitiveness}

To analyse and evaluate the relationship between productivity, employment and wage researchers (Pabedinskaitè, 2009; Dudzevičiūtė \& Čekanauskas, 2014) suggest using a correlation-regression analysis. This analysis is carried out in several stages:

- to collect the necessary statistical data and to systematize it;

- to establish a causal relationship between labour productivity, employment and wage;

- to describe the obtain results.

While determining the relationship between mentioned factors and assessing the strength of correlation relation based on the means of the correlation coefficients (Table 2).

Table 2. The values of correlation coefficient (source: Pabedinskaitè, 2009; Dudzevičiūtè \& Čekanauskas, 2014)

\begin{tabular}{|c|l|}
\hline Coefficient & Relation significance \\
\hline 0.00 & No relation \\
\hline $0.01-0.19$ & Very weak relation \\
\hline $0.20-0.49$ & Weak relation \\
\hline $0.50-0.69$ & Average relation \\
\hline $0.70-0.89$ & Strong relation \\
\hline $0.90-1.00$ & Very strong relation \\
\hline
\end{tabular}

For correlation-regression analysis these data are used: productivity (Figure 2) is expressed as the gross domestic product for one employee $(\mathrm{Y})$, employment data $\left(\mathrm{X}_{1}\right)$ (Figure 3$)$ - number of employees in thousands people and wage data $\left(\mathrm{X}_{2}\right)$ (Figure 4) - the amount of annual wage for one employee. Period 1995-2016 y. y. is selected, which means 22 observations have been made.

Using the correlation-regression analysis and reaching the greater accuracy two cases are analysed: the first case - using the annual data, the second case - annual changes. Correlation coefficient and t-statistic size is shown in Table 3.

In the first case the correlation coefficient is high (0.9844) and it means that there is a significant, very strong relation between labour produc- 
tivity, employment and wage. This is also confirmed by the value of $t$ statistics (3.9197), which shows that employment has a significant impact on productivity.

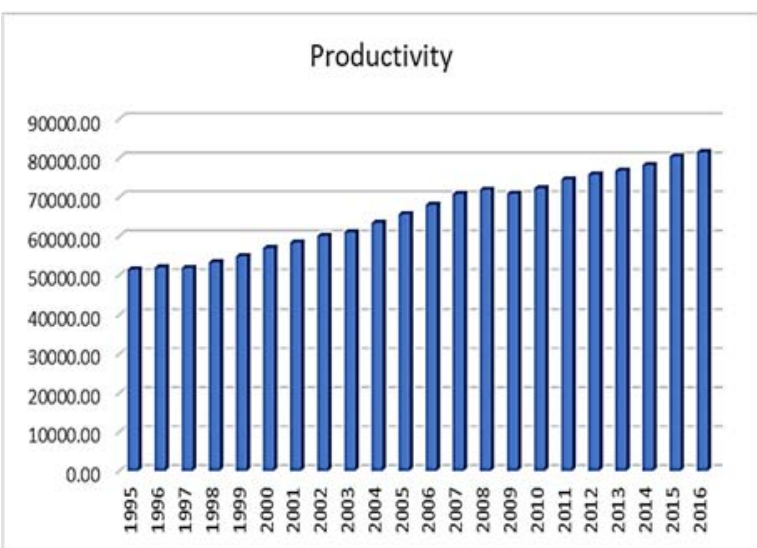

Figure 2. Productivity (gross domestic product for one employee) data 1995-2016 y. y.

(source: compiled by author based on Eurostat, 2017)

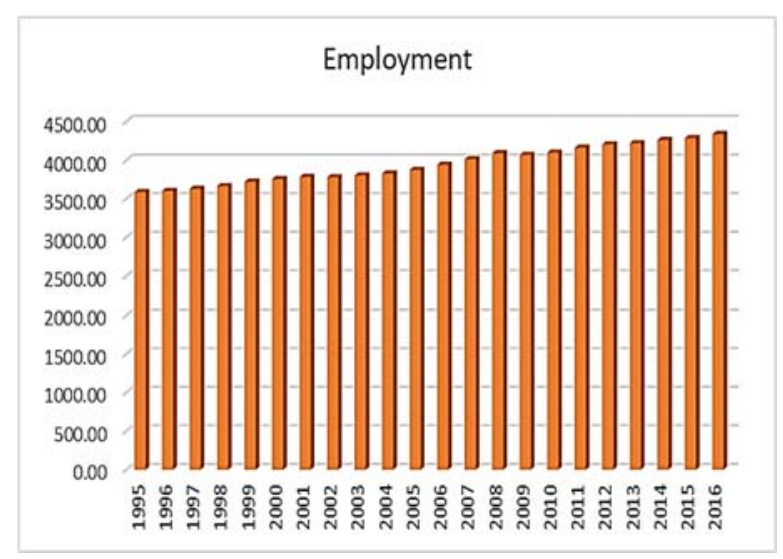

Figure 3. Employment data 1995-2016 y. y. (source: compiled by author based on Eurostat, 2017)

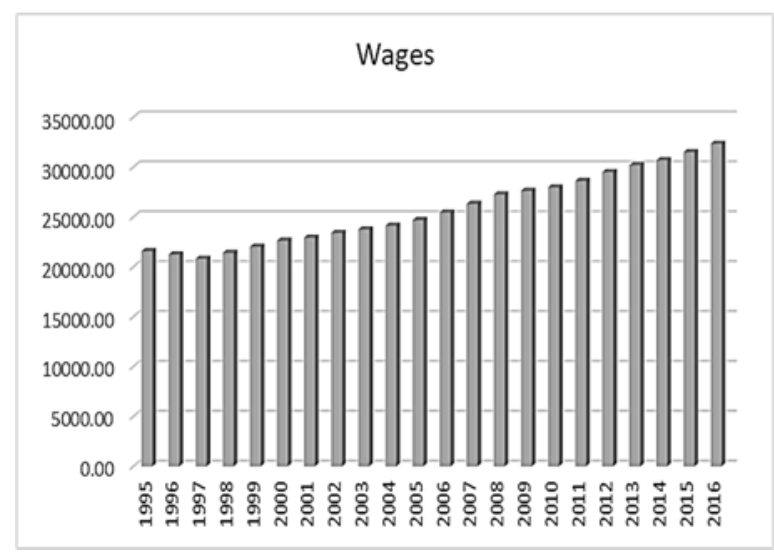

Figure 4. Wage data 1995-2016 y. y. (source: compiled by author based on Eurostat, 2017)
Table 3. The analysis of relationship between productivity, wage and employment in Lithuania in 1995-2016 y. y. (source: compiled by author based on calculations)

\begin{tabular}{|c|c|c|c|c|}
\hline & \multirow{2}{*}{$R^{2}$} & \multicolumn{2}{|c|}{ t statistics } & \multirow{2}{*}{$\begin{array}{c}\text { Relations } \\
\text { significance }\end{array}$} \\
\hline & & $\begin{array}{c}\text { Employ- } \\
\text { ment }\end{array}$ & Wage & \\
\hline 1 case & 0.9844 & 3.9197 & 0.3334 & $\begin{array}{l}\text { Significant, } \\
\text { very strong } \\
\text { relation }\end{array}$ \\
\hline 2 case & 0.3968 & 2.0060 & 1.3646 & $\begin{array}{l}\text { Non-signifi- } \\
\text { cant, weak } \\
\text { relation }\end{array}$ \\
\hline
\end{tabular}

In the second case the correlation coefficient is low $(0.3968)$ and it means that there is a nonsignificant, weak relation between mentioned three factors, although the value of $t$ statistic show that employment and wage have impact on productivity.

In summary, there is a very strong relation between labour productivity and employment and wages, but based on $2^{\text {nd }}$ case results the labour productivity is influenced also by other factors like inflation or innovation. This means that in the case of Lithuania productivity, wages and employment are rising accordingly.

\section{Conclusions}

- Based on the analysis of theoretical aspects of competitiveness it can be argued that the special attention should be given for labour productivity and the factors, which have influence on it. After the determination of appropriate wage and employment of the necessary amount of people the highest productivity can be reached, so here are the strongest relation between mentioned three factors.

- In the context of globalization competitiveness is a multidimensional factor that is closely related to the country's ability to adapt to the constantly changing socio-economic situation and to compete with other countries by capital size, the level of technical knowledge and special skills. It leads to a creation of preconditions for economic development. It follows that the main objective of competitiveness is to create the preconditions for learning and to adapt the modern technologies in activity.

- The competitiveness is affected by internal factors like human capital factors, the features of products and services, features or organization 
affect the competitiveness of a country through the competitiveness of individual industries. Also the level of competitiveness depends on the external factors like productivity, efficiency, trade liberalization and others global (have a macroeconomic character) factors and can be divided into four groups: totally uncontrolled, short-term uncontrolled, higher level and directly controlled factors. The greater attention is paid to the economic and social factors like wage and employment and their impact on productivity.

- In the macroeconomic perspective with globalization and the openness of countries to international trade, the growth of productivity and wage becomes the key factors that determine the international competitiveness of countries. The results of analysis shows that here is a strong relation between productivity, real wages and employment. Wage and unemployment level have a significant positive long-term impact on productivity. The growth of wage and unemployment leads to the increase in labour costs and to a possible loss of job. The growth of inflation and productivity are negatively related as inflation reduced incentives to work, investment has no return and capital price is growing.

- The results of the analysis of statistical data show that the productivity, employment and wage levels during the analysed period 1995 2016 y. y. are constantly growing. The results of the correlation-regression analysis showed that between labour productivity, employment and wages is a very strong relation, because correlation coefficient in first case is equal 0.9844 . On the other hand, in second case, where the changes are analysed, the correlation coefficient is equal only 0.3968 and shows, that productivity is also influenced by other factors like inflation or innovation level. It follows that productivity is rising only if the rates of wages, employment and other factor will be high. T statistic rate also shows, that employment has a great impact on productivity $\left(1^{\text {st }}\right.$ case shows that $t$ statistic is $3.9,2^{\text {nd }}$ case shows t statistic equal 2) but wage has no impact on productivity ( $\mathrm{t}$ statistic is smaller than 2).

- Based on the results of analysis and calculations author has one main suggestion. Nurturing the country's competitiveness it is necessary, first of all, to determine the right wage and to employ the necessary amount of people. It could lead to the higher productivity and accordingly to the economic growth. Meanwhile, it is necessary to pay an attention to inflation and innovativeness, because these factors also improve the productivity.

\section{References}

Abreu-Novais, M., Ruhanen, L., \& Arcodia, Ch. (2016). Destination competitiveness: what we know, what we know but shouldn't and what we don't know but should. Current Issues in Tourism, 19(6), 492-512. https://doi.org/10.1080/13683500.2015.1091443

Alexander, C. O. (1993). The changing relationship between productivity, wages and unemployment in the UK. $O x$ ford Bulletin of Economics and Statistics, 55(1), 87102.

https://doi.org/10.1111/j.1468-0084.1993.mp55001005.x

Bildirici, M., \& Alp, E. A. (2008). The relationship between wages and productivity: Tar unit root and Tar cointegration approach. International Journal of Applied Econometrics and Quantitative Studies, 5, 93-110.

Borowiecki, R., \& Siuta-Tokarska, B. (2015). Konkurencyjność przedsiębiorstw i konkurencyjność gospodarki Polski - zarys problemu. Nierówności Społeczne a Wzrost Gospodarczy, 41(1), 52-66.

Borowski, J. (2015). Koncepcje teoretyczne konkurencyjności międzynarodowej, optimum. Studia ekonomiczne, 4(76), 25-42.

https://doi.org/10.15290/ose.2015.04.76.02

Bruneckienė, J., \& Kilijonienè, A. (2011). Lietuvos regionų konkurencingumo klasterinè analizè. Management theory and studies for rural business and infrastructure development, 25(1), 60-69.

Camagni, R., \& Capello, R. (2014). Rationale and design of EU Cohesion Policies in a Period of Crisis with special reference to CEECs ${ }^{6}$. GRINCOH Working Paper Series. Policy Paper, 1, 1-20.

Dudzevičiūtè, G., \& Čekanauskas, J. (2014). Priežastinio ryšio tarp nedarbo ir emigracijos tyrimas Lietuvoje. Verslas: teorija ir praktika, 15(4), 294-301.

Dwyer, L., \& Kim, C. (2003). Destination competitiveness: Determinants and indicators. Current Issues in Tourism, 6(5), 369-414. https://doi.org/10.1080/13683500308667962

Eurostat. (2017). Statistical data. Retrieved from http://ec.europa.eu/eurostat/data/database

Gołębiewski, J., \& Podlińska, O. (2015). Determinanty konkurencyjności Polskich regionów w Unii Europejskiej. Przeglad zachodniopomorski XXX (LIX), 2, 7-20. https://doi.org/10.18276/pz.2015.2-01

Hondroyiannis, G., \& Papapetrou, E. (1997). Seasonality cointegration and the inflation, productivity and wages growth relationship in Greece. Social Science Journal, 34(2), 235-247.

https://doi.org/10.1016/S0362-3319(97)90053-7

Karaalp-Orhan, H. S. (2017). Labour productivity, real wages and unemployment: an application of bounds test approach for Turkey. Journal of Economic and Social Development, 4(2), 11-22.

Kleinhanss, W. (2015). Konkurencyjność głównych typów gospodarstw rolniczych w Niemczech. Zagadnienia Ekonomiki Rolnej, 1(342), 25-41. https://doi.org/10.5604/00441600.1146869

Kumar, S., Webber, D. J., \& Perry, G. (2009). Real wages, inflation and labour productivity in Australia. Munich Personal RePEc Archive, 19293, 1-12. 
Latruffe, L. (2010). Competitiveness, productivity and efficiency in the agricultural and agri-food sectors, OECD food. Agriculture and Fisheries Papers, 30, 1-62. https://doi.org/10.1787/5km91nkdt6d6-en

Lotfi, B., \& Karim, M. (2016). Competitiveness determinants of moroccan exports: Quantity-based analysis. International Journal of Economics and Finance, 8(7), 140148. https://doi.org/10.5539/ijef.v8n7p140

Meilienè, E., \& Snieška, V. (2010). Lietuvos pramonès konkurencingumo veiksniai eksporto politikos nuostatose. Viešoji politika ir administravimas, 31, 119-132.

Misala, J. (2011). Międzynarodowa konkurencyjność gospodarki narodowej. Warszawa: PWE.

Mora, T., Lopez-Tamayo, J., \& Surinach, J. (2005). Are wages and productivity converging simultaneously in euro-area countries?. Applied Economics, 37(17), 2001-2008. https://doi.org/10.1080/00036840500217655

Narayan, P. K., \& Smyth, R. (2009). The effect of inflation and real wages on productivity: new evidence from a panel of G7 countries. Applied Economics, 41(10), 1285-1291. https://doi.org/10.1080/00036840701537810

Pabedinskaite, A. (2009). Kiekybiniai sprendimu metodai. Vilnius: Technika.

Rakauskienè, G., \& Tamošiūnienè, R. (2013). Factors influencing national competitiveness. Business: Theory and Practice, 14(3), 177-187.

Schwab, K., \& Porter, M. E. (2007). The global competitiveness report 2007-2008. World Economic Forum: Geneva, Switzerland.

Šileika, A., Tamašauskienè, Z., \& Bartelienè, N. (2010). Comparative analysis of wages and labour productivity in Lithuania and other EU-15 countries. Socialiniai tyrimai, 3(20), 132-143.
Strauss, J., \& Wohar, M. (2004). The linkage between prices, wages and labour productivity: A panel study of manufacturing industries. Southern Economic Journal, 70(4), 920-941. https://doi.org/10.2307/4135280

Trpeski, P., \& Tashevska, B. (2009). Labor productivity and wages in the Republic of Macedonia. The Young Economists Journal, 1(13), 103-112.

Verbic, M., \& Kuzmin, F. (2009). Coefficient of structural concordance and an example of its application: labour productivity and wages in Slovenia. Panoeconomicus, $56(2), 227-240$ https://doi.org/10.2298/PAN0902227V

Wakeford, J. (2004). The productivity-wage relationship in South Africa an empirical investigation. Development Southern Africa, 21(1), 109-132. https://doi.org/10.1080/0376835042000181444

Walczak, W. (2010). Analiza czynników wpływających na konkurencyjność przesiębiorstw. e-Mentor, 5(37), 512.

Wychowanek, J. (2015). Tradycja w aspekcie budowania konkurencyjności małego przedsiębiorstwa, Prace naukowe Uniwersytetu Ekonomicznego we Wroctawiu, 401, 601-613.

Yordan, A., Nasution, A. S., \& Buang, N. A. (2017). The level global competitiveness and personal level development of aceh handicraft entrepreneurs, science. Engineering and Social Science Series, 1(1), 1-6.

Yusof, S. A. (2008). The long-run and dynamic behaviors of wages, productivity and employment in Malaysia. Journal of Economic Studies, 35(3), 249-262. https://doi.org/10.1108/01443580810887805

Žitkus, L., \& Mickevičienè, M. (2013). Konkurencingumas kaip regiono pletros siekinys, Viešoji politika ir administravimas, 12(3), 430-441. 